\title{
Setting up Frontiers, Crossing the Border: The Making of the Karina Tyrewuju
}

\author{
Gérard Collomb and Odile Renault-Lescure ${ }^{1}$
}

\section{1 \\ Introduction}

The European intrusion on the Guayana coasts adversely affected the mobility patterns of the native populations throughout this region, and caused a fragmentation of the ancient social and economic networks which linked the Amerindian groups, upsetting their social, economic, and also warlike relationships (Butt Colson 1973; Gallois 2005). Occurring simultaneously with a demographic collapse, these changes led to a creation and reinforcement of ethnic frontiers as an adaptive response to the changes that were occurring (see Whitehead 1993; Collomb and Dupuy 2009).

When European colonists arrived, the Kari'na formed a constellation of peoples speaking a Cariban language, settled on the coast between the Orinoco and the Approuague rivers. ${ }^{2}$ The members designated themselves as 'Kari'na'. They had created a taxonomy of their ethnic environment based on relationships of social and economic exchanges and on war (Hoff 1995). Later, European struggles over land separated the eastern Kari'na, living in modern day Suriname and French Guiana, from the western Kari'na, found in contemporary Venezuela, close to the middle reaches of the Orinoco River and in Guyana, near the Venezuelan border. Among these eastern Kari'na, a group calling itself 'Kari'na Tyrewuyu' had settled on both banks of the lower Maroni (Marowijne) and Mana rivers, and on the upper reaches of the Iracoubo River in contemporary French Guiana, straddling the political border between Suriname and French Guiana. This region had long remained on the fringe of Dutch and French colonial settlements in the Guianas because in the seventeenth and eighteenth centuries the French colony was focusing its main activities on the area between the Approuague and the Kourou rivers, while further west, the Dutch colony had shown little interest in the lands near the

1 Many thanks to Diane Vernon and the editors for her reading of the English version.

2 We adopt here the Surinamese spelling, except for their French Guianese toponyms, citations and examples.

(C) GÉRARD COLLOMB AND OdILE RENAULT-LESCURE, 2015 | DOI 10.1163/9789004280120_006 This is an open access chapter distributed under the terms of the Creative Commons AttributionNoncommercial 3.o Unported (CC-BY-NC 3.0) License. 
Maroni as most of its economic activity concerned sugar cane cultivated south and east of Paramaribo. These eastern Kari'na still thought of their social space as stretching up to the Essequibo and the Orinoco, but from the nineteenth century onwards they seldom went westward anymore to exchange goods or contract marriages. Their social and political life, and the processing of their ethnic identity, from then on took place in the territory between the lower Mana and Maroni rivers. Villages and/or families were frequently moving between the Dutch and French colonies, depending on the political developments of the time and/or, more frequently, in the hope of gaining advantages from one country or the other. For example, movement patterns were often based on considerations of the diversity and the quality of the goods offered by the Dutch and French colonial governments. Even if the idea of a border did not mean much to the Kari'na, they were aware that two 'nations' were competing for control of the Maroni river, trying to attract them to their 'nation' as hunters or as providers of goods for the colonial trade or, later, as a human presence against the people who were escaping from slavery. The Kari'na were thus keenly aware that they could benefit from this situation in various ways.

During the first half of the nineteenth century, French Guiana and Suriname entered a new stage of their colonial development. In French Guiana, an agricultural settlement was implemented in the western part of the colony, and from 1858 on, a penal colony (le Bagne) developed in the lower Maroni region, giving rise to the creation of the town of Saint-Laurent-du-Maroni, opposite the town of Albina on the Surinamese side of the Maroni River. In the Dutch colony, in the course of the eighteenth century, a dense network of plantations had been developing on the Suriname and Commewijne rivers, an area which was mostly off-limits for Amerindians. They, therefore, had to restrict their activities to the Marowijne region, on the Surinamese side of the Maroni River. However, this area was also of interest to the escaping slaves or Maroon populations (Ndyuka, Aluku, Bakabusi sama) who fled to or settled in the forests west of the Marowijne/Maroni River. The two population groups therefore became competitors. These co-occurrences, that had previously prevented the Tyrewuju from maintaining a distance from the colonial places, materialised at a moment when the Kari'na Tyrewuju were at their lowest demographic level, reduced to only a few hundred people. They became more and more limited in their collective mobility, and their economy became more dependent on the colony's activities. From this period, their contacts with other Amerindian groups diminished sharply, and in the second half of the nineteenth century they ended up in a new world that they had to share with other, culturally different populations, namely French and Surinamese Creoles, Maroons, and Europeans. The history of the Kari'na, their ethnic identification (either self- 